\title{
Nature Tourism Development Strategy in Belangian Village Aranio District Banjar Regency, South Kalimantan
}

\author{
Adisty Endang Fawzia Abdi Fithria, Hafizianoor \\ Student of Master Program of Forestry Science, Graduate Program \\ University of Lambung Mangkurat, Faculty of Forestry, South Kalimantan, Indonesia
}

\begin{abstract}
Tourism is one utilization source power nature can worth economy high for something area that manage source power natural to be something the place tours that can interest the visitor well from in or from abroad, in addition to worth high economic and able to absorb power work and push development investment. However development region object tour not yet done on some region object tour. Research this aiming for identify strategy development and implementation strategy development comprising from some dimensions, i.e. Goals, Policies and Programs that will produce something strategy from some definition strategy. Research this use method research descriptive qualitative. Data type consists from the primary data obtained through interview and observation. While secondary data originated from document report problem that will examined, writing and results research about Strategy Development Object Tour. Research results this to show that strategy development carried out Service Culture and Tourism Banjar Regency is Strategy as plans and more optimizing potency source power nature and source extensive water power for support services tourism for the sake of realization enhancement income area especially around HR location tour. As for some implementation strategy Identified development under taken namely, (1) Development conducted should focused on one point, (2) involvement all related elements, (3) Identify in a manner thoroughly to object to be developed, (4) Doing training well guide tourist, perpetrator travel , and manager travel, (5) Coordination who continue do to government and citizens around region object tour.
\end{abstract}

Keywords: tourism, tourism development, South Kalimantan

DOI: $10.7176 / J E S D / 10-18-09$

Publication date:September $30^{\text {th }} 2019$

\section{Introduction}

Tourism development intend for improve state income or foreign exchange (by specifically) as well improve welfare community (by general) as listed on the contents Instructions President No. 9 of 1969 Chapter II Article 2. With thus tourism could called as something industrial complex. Tourism Richard Sihite in Marpaung and Bahar (2000) are something the journey under taken to while time, held from something the place the place of others to leave the place originally, with something planning and with mean not for attempted or looking for living in the place visited, but solely for enjoy activities sightseeing and recreation or for meet diverse desires variety. Tourism is one industry New afford provide growth Rapid economic in p chance work, income, level life and depth activate sector other production in the recipient country tourists.

In a manner aspect in tourism is considered the most important is aspect economy and got most attention in sector tourism because in hold up something the trip people issue costs. While for areas visited traveler able to make field work for get money from traveler that is through the people who provide freight, provide many kinds of services, attractions and so on. One of them aim from development tourism that is obtain profit in a manner economy. Because Indonesia is one of the countries in the world that has many potency natural well mainland or ocean (beach ). Indonesia becomes center attention for settled and developed his business respectively, that issupported with condition arable land, while oceans and beaches to be potency waters.

For developed countries common place done and being needs life everyone is traveled, $\mathrm{p}$ this because of sector increasing tourism developing to be drive economy. According to the opinion of David Scowsill, president and CEO of WTTC, utilization opportunity business in tourism need regional and place authorities visits, in particular for developing countries in create climate more business well for investors to invest in field infrastructure and resources power humans. Various policy at the level national can also do more many visa policy and run Policy tax by the government. It could to be pusher in period long for do with right target by the developer tourism.

Tourism has been made into as one sector economy most important in Indonesia. Because of that field tourism got attention in a manner serious from government because considered as sector economy important, then from that issued Constitution Year 2009 No. 10 about tourism is as basic law in tourism. Based on Constitution that is have some aim from organization tourism, i.e. improve growth economy, improve welfare people, delete poverty, overcoming unemployment, preserving nature, environment and source power, advance culture, lift up image nation, foster a sense of love homeland, streng then unity and teak self nation, as well streng then brotherhood deliver the nation.

As for other reasons that make it sector tourism made into commodity mainstay Besides oil and gas as commodity support for continuity development in a manner national among others: pattern travel activities 
conducted tour continously more and more increase from year after year, tourism is not so affected by turm oil world economy, besides growth also fast compared with growth economy world, improve activities economy level area and presence development tourism looked more the real influence double, commodity activities tourism not know limitation or quota as commodity other, potential Indonesia holidays scattered throughout, as well astourism has been to be needs life humans in general (Suwantoro, 1997).

Management forest in the region Valley Kahung is long this already pointing for prepared as area aim tour nature, however not yet give away the maximum contribution for enhancement welfare surrounding community, because still there is potential that has not identified especially tour nature and lack involvement society in management tour. Target management region this not yet able to protect in a manner intact whole ecosystem and values noble culture community contained there in.

Contribution big in development tourism originated from development visit tourists. Government South Kalimantan Province and Government Banjar Regency recommends a strategy for means enhancement tourism in the Belangian village, though strategy this not yet able to give away a significant increase in optimization potency of tourism because not yet involving society local. So that in order optimizing potency it is also supported with enhancement visit traveler needed a strategy others inside effort for develop sector tourism in the Belangian village. In strategy this do through perception tourists and society local. Based on strategy that is expected able to answer needs tourists and optimize activities tour and could improve income society local, with permanent maintain aim main in development tourism.

Limitation of study space on Objects Tour Kahung Valley Belangian Village is done so that the complexity of existing dynamics can be recognized better for later from the various research results obtained, it is expected to be a pre liminary knowledge to find solutions to the complexity of tourism dynamics that occur in other parts of the Banjar Regency.

\section{Materials and methods}

The equipment used during the study included question naires, cameras for documentation, stationery, the Administrative Map of Banjar Regency, tally sheet, GPS and computer (ArcGIS Software). Research implemented in the object tour natural Kahung Valley in the Belangian Village is located in region administration subdistrict Aranio, Banjar Regency, South Kalimantan with have large area of 24,021 ha. Research this held for 6 (six) months, May through month October 2018 comprising from activities field data collection, data processing up to with preparation report thesis. The stages of research are as follows:

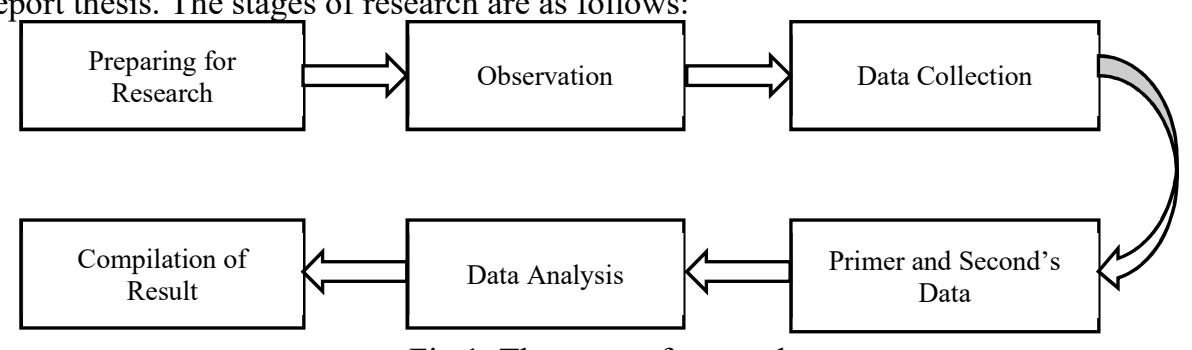

Fig 1. The stage of research

The study was conducted using non-experimental methods, namely descriptive exploratory, field observations and literature study literature to collect the data needed.

Object tour need for human in obtain passion, freshness mind after do activities tour. Not every object tour at one the place could give away convenience to visitors who come. Because of that there is some It is important as terms existence object tour that is if something object tour that is have power Pull then the tourists who visit even more increase, however when object tour that is not have power Pull then there are also few tourists visiting. Existence something object travel in general not noticed by the manager object tour that is so that less in demand traveler for visit to object tour that is.

\section{Results and Discussion}

From the results of the study, it was found that the natural attractions of Kahung Valley have an attraction including uniqueness, natural beauty, prominent natural resources, the integrity of natural resources, sensitivity of natural resources, types of tourism activities. The flora found in the Kahung Valley region has a unique uniqueness from the flora found in the land of the forest, the difference is seen in the type of vegetation that grows in this area.

Based on observations there are several types of large diameter trees such as Binuang, Belangiran, and giant Meranti which are still preserved in this place, which has the same diameter as three adults. This species is a tropical forest dwelling tree, from the Dipterocarpaceae tribe and found ant plant species attached to the tree or called Myrmecodia Tuberosa has a large stem resembling a tuber.

Forest in the Belangian village including in region protected. In the forest protected usually many there is tree adoption or called with trees protected its existence, for keep preservation, arrangement of water systems, as 
sourceseed for regeneration. Type The dominant tree is Meranti. Presence tree adoption of course many interesting attention tourists.

Tourist area natural Kahung Valley have enough flora potential diverse with attractive conditions. Type very attract tourists is type orchid. What's in the Valley region Pull Kahung become tourists. Referring to the criteria proposed by Fandeli (1992), that flora potential with number of diverse have very meaning support for asset tour.

Based on the quality of fauna diversity according to Fandeli (1992) the number of fauna found in Kahung Valley is 35 species and this is included in the criteria for the quality of faura diversity which is very good ( $>16$ species of animals). And the type of fauna found in the Kahung Valley could 2 seen in the following this table.

Object tour Kahung Valley is a region forests located in the Maimed village, the same as area Other existing around child river, transportation favorite headed to Kahung Valley is use traditional motor boat called with klotok by the community local. Klotok even this only deliver to the nearest village, i.e. Belangian village is inhabited by around 103 heads the family.

Travel use klotok need time approximately 2 hours before to dock in the Belangian village. Klotok this can rented with cost around IDR 250,000 for travel round-trip to Belangian village.

Amounts, variations and attractions unique that can be done in the region Valley Kahung very interesting because the amount number and level variation attractions there such as the scenic potential zone and recreational zone. While reviewed from famous attractions interesting because its height interest people were very agree existence development tourist on site Belangian Village without should change circum stances the actual nature.

Table 1. Flora around the Nature Tourism Area in Kahung Valley Belangian Village

\begin{tabular}{cll}
\hline No & \multicolumn{1}{c}{ Scientific Name } & \multicolumn{1}{c}{ Family } \\
\hline 1. & Shorea spp & Dipterocarpaceae \\
2. & Octomeles & Datiscaceae \\
3. & Shorea belangeran & Dipterocarpaceae \\
4. & Eusideroxylon zwageri & Dipterocarpaceae \\
5. & Dipterocarpus & Dipterocarpaceae \\
6. & Coelogyne & Orchidaceae \\
& Dendrobium & \\
& Phalaenopsis Belina & \\
& Cymbidium & \\
& Dendrobium Scundum & \\
& Vanda & \\
& Aerides & \\
7. Gramatuphilum & Swietenia macrophylla & Meliaceae \\
8. & Ficus benjamina & Moraceae \\
9. & Tectona Grandis & Lamiaceae \\
10. & Cariwaya sp & Dipterocarpaceae \\
11. & Amanita sp & Amanitaceae \\
12. & Myrmecodia Tuberosa & Rubiaceae \\
13. & Calamus sp & Arecaceae \\
14. & Taenitis & Pteridaceae \\
15. & Agathis & Araucariaceae \\
16. & Rhodomyrtus & Myrtaceae \\
17. & Toxicodendron radicans & Anacardiaceae \\
18. & Santiria tomentosa & Burseraceae \\
19. & Ilex cymosa & Aquifoliaceae \\
20. & Memecylon leavigatum & Melastomataceae \\
21. & Caethocarpus grandiflorus & \\
22. & Mesia sp & \\
23. & Arthocarpus kemando & \\
alalty then landscape attractions artificial to
\end{tabular}

Based on criteria level visual quality then landscape attractions artificial to the campsite on site places Rest area with a rating of 5 (very interesting) seen in the Fig 2 below.

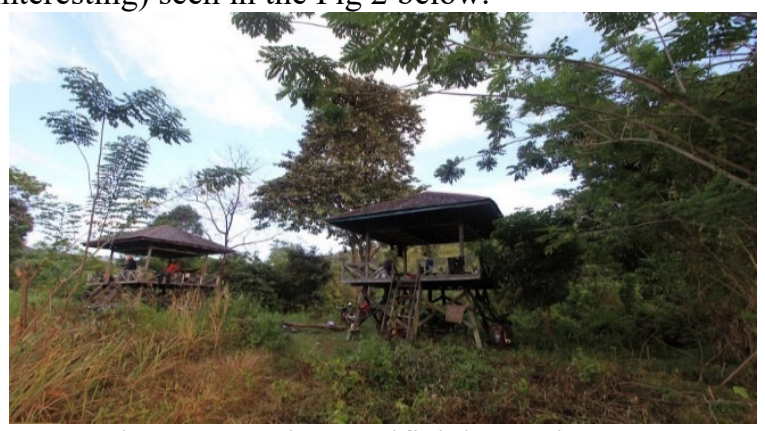

Fig 2. Attractions artificial camping area

Based on criteria level visual quality then landscape attractions artificial on location tour natural for boat go around river/ strait river in the Belangian village with rating 4 (relatively natural interesting). 


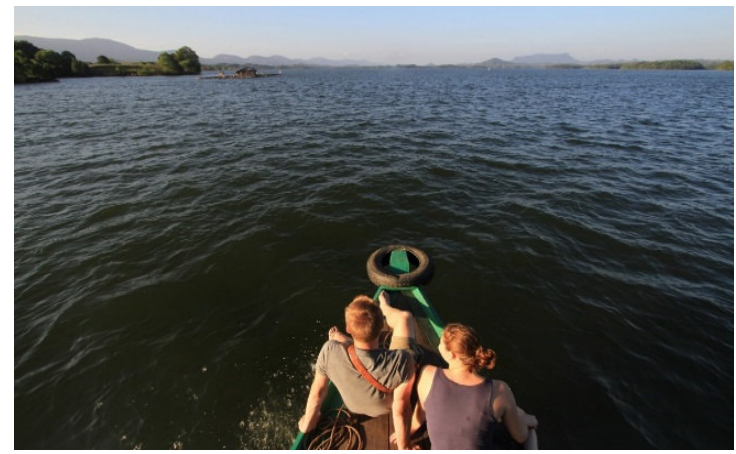

Fig 3. Artificial attractions boat river

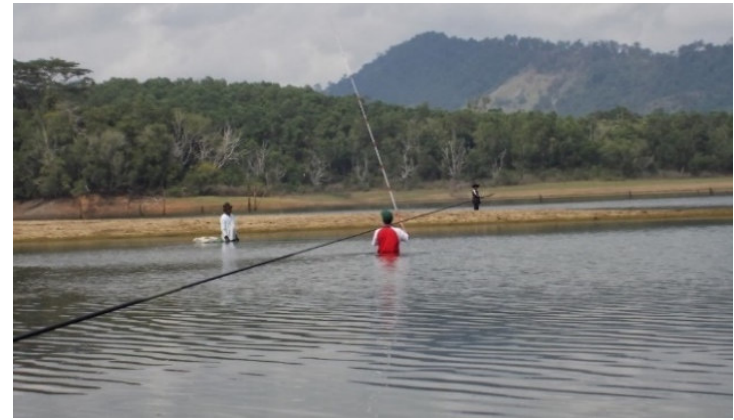

Fig 4. Artificial attractions fishing area

Based on criteria level visual quality then landscape attractions artificial for Fishing Fish around river in the Belangian village with a rating of 5 (very interesting) seen in the picture 3 and image 4 above.

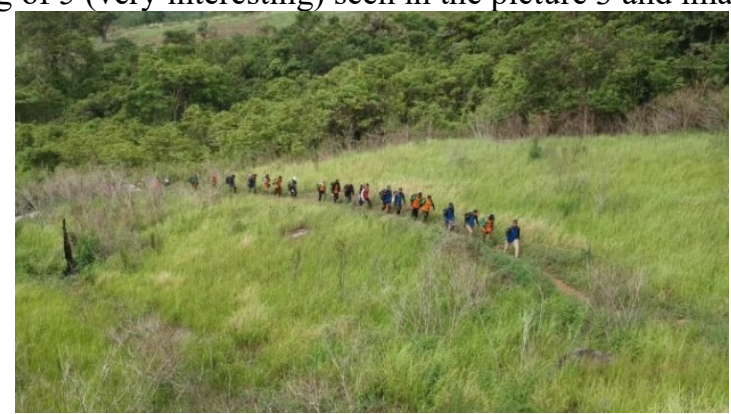

Fig 5. Artificial attractions tracking 
Table 2. Fauna around the Nature Tourism Area in Kahung Valley Belangian Village

\begin{tabular}{lll}
\hline No & \multicolumn{1}{c}{ Name of Fauna } & \multicolumn{1}{c}{ Scientific Name } \\
\hline 1. & Bangkui & Macaca nemenstrina \\
2. & Katak & Bufo melanostictus \\
3. & Hirangan /Lutung & Presbytis frontata \\
4. & Menjangan & Cervus unicolor \\
5. & Kelelawar & Hipposideros commertoni \\
6. & Tupai & Tupaia graclis \\
7. & Lebah & Apis koschevnikovi \\
8. & Monyet Ekor Panjang & Macaca fascicularis \\
9. & Kucing Hutan & Felis bengalensis \\
10. & Babi Hutan & Sus barbatus \\
11. & Beruang & Helarctos malayanus \\
12. & Anjing & Canis familiaris \\
13. & Kupu-Kupu & \\
14. & Ular Sawa & Phyton sp \\
15. & Salimbada & \\
16. & Jangkrik & Gryllus assimilis \\
17. & Capung & Neurothemis sp \\
18. & Burung Bubut & Contropus bengalensis \\
19 & Burung Burak-burak & Amauranis phoenicurus \\
20 & Burung Kelayangan & Hirundo tahitica \\
21 & Burung Cabak & Caprimulgus affinis \\
22 & Burung Cuit Damar & Anthreptes sp \\
23 & Burung Curiak & Prinia flaviventris \\
24 & Burung Kutilang & Pycnonotus aurigaster \\
25 & Burung Pipit & Lonchura gulgulus \\
26 & Burung Punai ari & Treron vernans \\
27 & Burung Cuit Habang & Aethophyga siparaja \\
28 & Burung Tekukur & Streplopelia chinensis \\
29. & Bekantan & Nasalis larvatus \\
30. & Landak & Hystrix brachyura \\
31. & Ular Tadung & Naja sp \\
32. & Kadal & Mabouya fascicularis \\
33. & Biawak & Varanus borneanus \\
34. & Bidawang & Amyda cartilaginea \\
35. & Musang & Paradoxurus hermaproditus \\
\hline 1 & Artificial attractions Tracking
\end{tabular}

Based on criteria level visual quality then landscape Artificial attractions Tracking Kahung Valley in the Belangian Village with a rating of 5 (very interesting).

Concept that is developed in concept room recreation and facilitation. Besides enjoy Forest Kahung Valley who is still very natural. Attractions artificial support attractions tour natural this could in the form of camping, tracking, fishing fish and boat. The inventory ratting attractions artificial seen on table 3 on bottom:

Table 3. Ratting of Inventory Artificial Attraction

\begin{tabular}{|c|c|c|c|}
\hline No & Artificial Attraction & Rating & Information \\
\hline 1 & Camping Place & 5 & Interpretation of number on ratting: \\
\hline 2 & $\begin{array}{l}\text { The Boat goes around in the Belangian's } \\
\text { river }\end{array}$ & 4 & $\begin{array}{l}\text { 1. Very not interesting } \\
\text { 2. Not interesting }\end{array}$ \\
\hline 3 & Fishing Place around in the Belangian's river & 5 & $\begin{array}{ll}\text { 3. } & \text { Seems interesting } \\
\text { 4. } & \text { Natural relative interesting } \\
\text { 5. } & \text { Very interesting }\end{array}$ \\
\hline 4 & Tracking Kahung Valley & 5 & \\
\hline
\end{tabular}

Based on criteria level visual quality then landscape "Kahung Valley" included type A with score of 30 (quality high) because Kahung Valley have authenticity region and have beauty nature still very experience, results of inventory and assessment and gift score refer to the criterion level visual quality with parameters from Bureau of Land Management. In a manner complete description judgment as in table 4. 
Table 4. The result of assessment natural attraction in Kahung Valley

\begin{tabular}{|c|c|c|c|}
\hline No & Landscape & Value & Information \\
\hline 1. & Landform & 5 & $\begin{array}{l}\text { High vertical reliefs are aimed at the presence of peaks, indicated by the presence of giant rock } \\
\text { outcrops or amazing surface variations; erosion resistant or dominant features that are very } \\
\text { striking }\end{array}$ \\
\hline 2. & Vegetation & 5 & Many types and vegetations are interesting, which are shown in patterns, textures and shapes \\
\hline 3. & Water & 5 & Clear, clean, flowing, rippling or any component of the dominant water \\
\hline 4. & Color & 3 & $\begin{array}{l}\text { There are various types of colors. There are conflicting colors from the soil, rocks and vegetation } \\
\text { but not the dominant element of beauty }\end{array}$ \\
\hline 5. & $\begin{array}{l}\text { Surrounding } \\
\text { scenery }\end{array}$ & 5 & The scenery nearby greatly affects the quality of the scenery \\
\hline 6. & Dearth & 5 & A typical area (different with other objects \\
\hline 7. & Modification & 2 & $\begin{array}{l}\text { Construction of facilities such as electrical installations, waterways, houses, provides } \\
\text { modifications that can add diversity or visuals; or if there are no modifications at all }\end{array}$ \\
\hline & Total & 30 & \\
\hline
\end{tabular}

For get picture from society about development travel in the Kahung Valley, then do spread question for knowing perceptions and preferences society if will do development tour. Perception this known from understanding or view they among others is Location Kahung Valley and its surroundings can be made the place sustainable tourism, desire for involved directly in development tour or management and participation participate in active in the future come in. In part big society belangian village the respondent have sufficient under-standing well about existence aim development tour because look potency owned natural Kahung Forest. A total of 103 families were made respondent from 335 total residents in the Belangian Village.

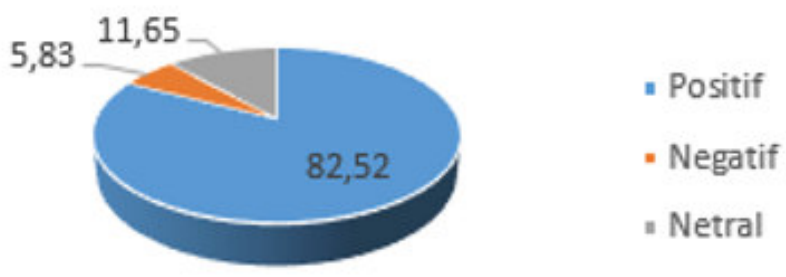

Fig 6. Community opinion diagram about development object tour

Almost in part big society argue that development object tourism in the Belangian village, is of a nature positive $(82.52 \%)$, thinking negative $(5.83 \%)$ where as be have neutral $(11.65 \%)$. Neutral society about development tourism in the Belangian village because believes if region this could developing then impact positive for economy they and negative because they afraid if many visitors who come will bring in impact bad and influence for society around.

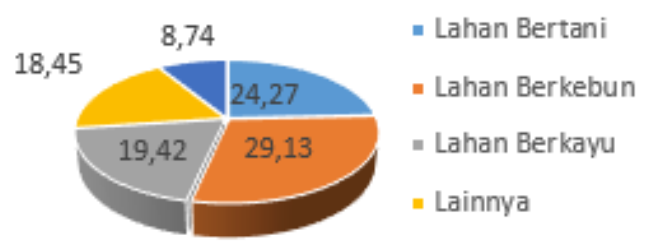

Fig 7. Diagram of Dependency to results nature in the region tour

Dependency to results nature in the region tour Belangian village that is land farming (24.27\%), land gardening (29. 13\%), land woody $(19.42 \%)$ and others $(18.45 \%)$. And who doesn't dependency to results nature in the Belangian village $(8.74 \%)$.

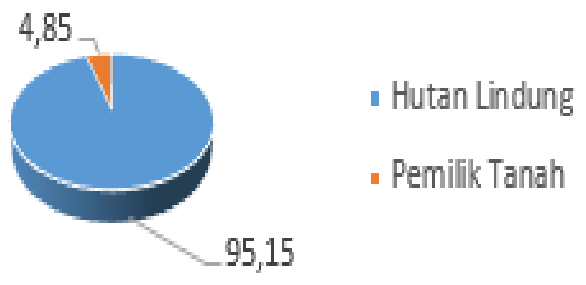

Fig 8. Land Status Chart region Belangain Village

Land status society to region before made into the place tour that is owner the remain land (4.85\%) as much 
$(95.15 \%)$ is region the forest. Almost all over respondent knowledge about plan development tourism in the Belangian village that is total $(94.17 \%)$ know about it and just $(5.83 \%)$ were not knowing in a manner for sure, because according to society party who wants develop object tour in place they not do socialization especially first.

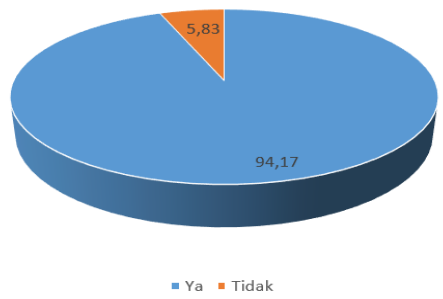

Fig 9. Diagram Knowledge about plan development tour

Intended use society village Warranties and those who want develop object tour this want designation for recreation as much as $(24.27 \%)$, for permanent make Regional conservation area total $(72.82 \%)$ and for make the cultivation area fish bargain as much $(2.91 \%)$.

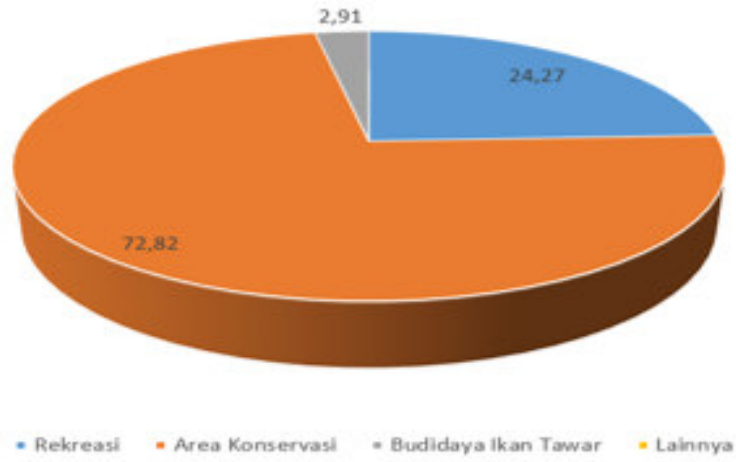

Fig 10. Use of the hope community in the Belangian village

We know for headed region tour embraced time is not a little for headed location of our want it. For society around and travel there is some way headed region tour Kahung Valley which is riding a vehicle general (motorcycle tax) of (4.85\%), choosing walk for way The most widely done by visitors namely $(82.52 \%)$ while those who choose use bike mountain $(9.71 \%)$ and use a private motorbike ride total $(2.91 \%)$ records for the visitors who use their own motors expected be careful because almost in part big terrain traversed not could using a motorbike. Almost all who argue that object tourist Belangian village could immediately developed become a tourist area nature. Because of them reasoned that tour Kahung Valley have power Pull alone compared with tours natural in Banjar district.

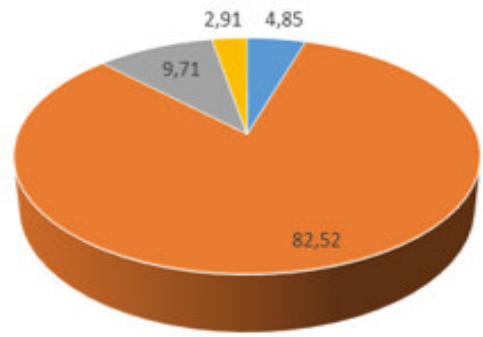

- Naik Kendaraan Umum "Berjalan Kaki "Naik Sepeda * Naik Motor

Fig 11. Diagram of Way headed region tour Kahung Valley

As many as (87.38\%) people in the area ready come along involved in management region tourism and $(12.62 \%)$ less ready involved directly because reason they not enough have knowledge for develop tour with good and right. 


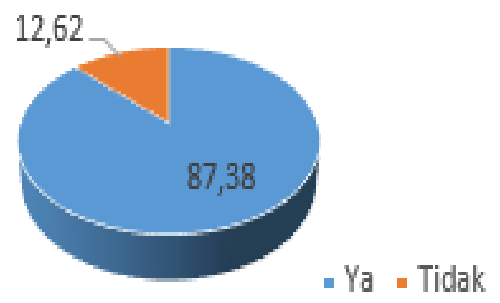

Fig 12. Diagram of Awareness to be involved in management region tour Kahung Valley

Results obtained at the time do Interview directly about the extent to which knowledge they about tourism, as many as (82.52\%) respondents know it and as much (17.48\%) less know. Means transportation in the Belangian village generally taken through water transportation with use motor boat (raft). While transportation land only can reachable through Village Kiram with condition region mountainous and hilly and roads have been hardened with stone mountain.

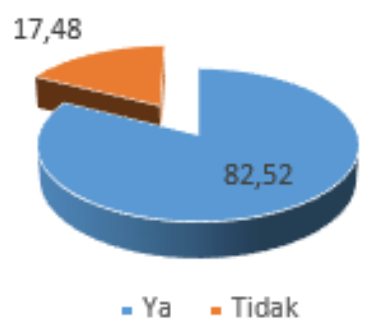

Fig 13. Diagram Knowledge about tour

\section{Conclusion}

Based on the results obtained from this study it was concluded that potential can developed in the Belangian village for development tour Kahung Valley is tour natural, water attractions and tourist culture. Score for value attractions nature and attractions Average artificial highly interesting profit development object tour Kahung Valley in the Belangian village. Utilization potency resource natural extensive in the region Belangian village could support services tourism could materialized seen from aspect economic, environmental and social. Perception and preference community 100\% hope Belangian Village developed become a tourist area nature, $87.38 \%$ are willing come along involved in management region tour.

\section{Recommendation}

Research this produce some recom-menddations include: Utilization potency resource natural extensive for support services tourism for the sake of realization enhancement opinion area, equip infrastructure supporters development object tour Valley Kahung especially as roads, bridges, facilities infrastructure and others, Establish in the Spatial Planning as region tourism in the District Aranio Kabupaten Banjar, Conducting promotion with use technology as television, radio and website. Search planter stock for development object tour Valley Kahung, you can from the budget government or help from a swast and Increase awareness to society about importance development tour.

\section{References}

Fandeli Ch, 1992. "Analysis About Impact Environment, Basic and presentation prinsif in Development". Publisher Liberty. Yogyakarta.

Fandeli, C. Dan Mukhlison. 2000. "Ecotourism business". UGM. Yogyakarta.

Fandeli Ch, 2001. "Foundations Management Tourism Nature". Liberty. Yogyakarta.

Gamal. 2002. "On the fundamentals Tourism". Yogyakarta. Andi Publisher.

Instructions President No. 9 of 1969 CHAPTER II Article 2 "About Development Tourism".

Marpaung, Happy \& Herman Bahar, 2000. "Introduction to Tourism". Bandung; Alfabeta Publisher.

Mayer, Koen 2009, "Basic Implementation Guide Ecotourism". Jakarta. UNESCO Office.

Suwantoro, Gamal, 1997, "The foundations Tourism". Publisher Andi. Yogyakarta

Pendit, Nyoman. 1999. "Science Tourism". Jakarta. Academy Tourism Trisakti.

Pitana, I Gede and Gayatri, Putu G. 2005. "Sociology Tourism". Yogyakarta. 